\title{
Chryseobacterium arothri Campbell et al. 2008 is a later heterotypic synonym of Chryseobacterium hominis Vaneechoutte et al. 2007
}

Correspondence

Peter Kämpfer

peter.kaempfer@umwelt.

uni-giessen.de

\author{
Peter Kämpfer, ${ }^{1}$ Mario Vaneechoutte ${ }^{2}$ and Georges Wauters ${ }^{3}$ \\ ${ }^{1}$ Institut für Angewandte Mikrobiologie, Justus-Liebig-Universität Giessen, Germany \\ ${ }^{2}$ Department of Clinical Chemistry, Microbiology \& Immunology, University of Ghent, Ghent, Belgium \\ ${ }^{3}$ Microbiology Unit, Faculty of Medicine, University of Louvain, Brussels, Belgium
}

\begin{abstract}
The type strains of the species Chryseobacterium arothri (DSM 19326 ${ }^{\top}$ ) and Chryseobacterium hominis $\left(\mathrm{NF802}{ }^{\top}\right)$ were compared in order to clarify the taxonomic relationship of the two species. The 16S rRNA gene sequences of the two strains shared $99.9 \%$ identity. DNA-DNA pairing studies between the two strains showed $100 \%$ (reciprocal, $76.0 \%$ ) relatedness. Phenotypic data, including fatty acid patterns and substrate utilization profiles, showed no pronounced differences between the type strains of the two species. On the basis of these results, we propose the reclassification of Chryseobacterium arothri Campbell et al. 2008 as a later heterotypic synonym of Chryseobacterium hominis Vaneechoutte et al. 2007.
\end{abstract}

Chryseobacterium arothri was described by Campbell et al. (2008) for a novel strain isolated from the kidney of a pufferfish. A few months earlier, Chryseobacterium hominis was described by Vaneechoutte et al. (2007) for clinical isolates biochemically similar to CDC groups II-c and II-h. The two species were described at nearly the same time. Soon after the publication of the two studies, it became obvious that the type strains of these species were closely related on the basis of $16 \mathrm{~S}$ rRNA gene sequence similarities. The $16 \mathrm{~S}$ rRNA gene sequences of $C$. arothri $\mathrm{P} 2 \mathrm{~K}^{\mathrm{T}}$ (GenBank accession no. EF554408) and C. hominis $\mathrm{NF}_{02}{ }^{\mathrm{T}}$ (AM261868) shared $99.9 \%$ similarity. A further comparative phenotypic analysis supported this finding.

The original descriptions were based on the properties of strains of the two species grown on tryptic soy agar at $28{ }^{\circ} \mathrm{C}$. However, the duration of incubation differed (i.e. $24 \mathrm{~h}$ for the type strain of $C$. arothri and $48 \mathrm{~h}$ for four $C$. hominis strains). In order to compare the fatty acid profiles of the two species grown under exactly the same conditions, the type strain of C. arothri (DSM $19326^{\mathrm{T}}$ ) was grown in this study for $48 \mathrm{~h}$ on tryptic soy agar at $28{ }^{\circ} \mathrm{C}$. Fatty acid methyl esters were prepared, separated and identified according to the instructions of the Microbial Identification System (MIDI, Microbial ID; Kämpfer \& Kroppenstedt, 1996), in order to study the strains simultaneously. The fatty acid profiles of the two strains are shown in Table 1. No significant differences in the fatty acid profiles were found.

Biochemical and morphological tests were again performed as described previously (Laffineur et al., 2002; Schreckenberger et al., 2003). Assimilation-alkalinization of organic compounds was detected on Simmons' citrate agar base, replacing citrate with $0.2 \%(\mathrm{w} / \mathrm{v})$ of various organic substrates, according to Martin et al. (1981). Enzyme reactions were determined using diagnostic tablets from Rosco. The $\mathrm{KOH}$ test was used to detect flexirubin pigments (Bernardet et al., 2002). All 11 strains of $C$. hominis and the type strain of C. arothri were positive for oxidase and catalase activities, growth at 30 and $37{ }^{\circ} \mathrm{C}$ (with optimal growth at $30^{\circ} \mathrm{C}$ ), aerobic growth, acid production from glucose, maltose and ethylene glycol, indole production, hydrolysis of aesculin, starch and gelatin, alkaline phosphatase, trypsin (benzyl arginine arylamidase) and pyrrolidonyl aminopeptidase (except CCUG 36749) activities and resistance to desferrioxamine. Acid production from sucrose, reduction of nitrate and nitrite and hydrolysis of tyrosine were variable among the C. hominis strains. Schreckenberger et al. (2003) reported a positive nitrate reduction (90\%) in group II-c and a negative result in group II-h. However, in our series, four strains out of seven with a II-h profile reduced nitrate. All strains were negative for production of flexirubin pigments, growth at $42^{\circ} \mathrm{C}, \mathrm{H}_{2} \mathrm{~S}$ production on Kligler agar, Tween 80 hydrolysis, alkalinization of citrate on Simmons' agar and activities of ornithine and lysine decarboxylases, urease, arginine dihydrolase and L-phenylalanine deaminase. Other important characteristics used to differentiate Chryseobacterium species are shown in Table 2 for $C$. hominis and C. arothri.

DNA-DNA hybridization experiments were performed with strains C. hominis $\mathrm{NF}^{2} 02^{\mathrm{T}}$ and C. arothri DSM $19326^{\mathrm{T}}$. DNA isolation and DNA-DNA hybridization were done as described previously (Kämpfer et al., 2003). Results 
Table 1. Cellular fatty acid profiles of strains of C. hominis and C. arothri

Data for C. hominis strains were taken from Vaneechoutte et al. (2007). For unsaturated fatty acids, the position of the double bond is located by counting from the methyl $(\omega)$ end of the carbon chain; cis isomers are indicated by the suffix $c$. Values are percentages of total fatty acids; fatty acids amounting to $<1 \%$ of the total fatty acids in all strains studied are not shown. tr, Traces $(<1 \%)$; ND, not detected.

\begin{tabular}{|c|c|c|c|}
\hline \multirow[t]{2}{*}{ Fatty acid } & \multirow[t]{2}{*}{ C. hominis $(n=4)$} & \multicolumn{2}{|c|}{ C. arothri DSM $19326^{\mathrm{T}}$} \\
\hline & & This study & Campbell et al. (2008) \\
\hline iso- $\mathrm{C}_{13: 0}$ & $\operatorname{tr}-4.8$ & 1.3 & 5.0 \\
\hline Unknown $13.565^{\star}$ & ND-6.9 & 7.1 & ND \\
\hline iso- $\mathrm{C}_{15: 0}$ & $22.4-35.8$ & 27.5 & 35.3 \\
\hline anteiso- $\mathrm{C}_{15: 0}$ & $8.1-9.6$ & 6.4 & 5.5 \\
\hline Summed feature $3 \dagger$ & $7.5-17.8$ & 12.2 & 13.9 \\
\hline $\mathrm{C}_{16: 1} \omega 5 c$ & ND & 1.3 & 2.1 \\
\hline $\mathrm{C}_{16: 0}$ & $\mathrm{ND}-3.0$ & $\operatorname{tr}$ & 1.5 \\
\hline iso- $\mathrm{C}_{15: 0} 3-\mathrm{OH}$ & $4.3-6.0$ & 5.2 & 4.5 \\
\hline $\mathrm{C}_{16: 0} 3-\mathrm{OH}$ & $\mathrm{ND}-4.8$ & 3.8 & 5.1 \\
\hline iso- $\mathrm{C}_{17: 1} \omega 9 c$ & 15.6 & 7.2 & ND \\
\hline Summed feature $4 \dagger$ & 2.4 & 1.0 & 6.3 \\
\hline iso- $\mathrm{C}_{17: 0} 3-\mathrm{OH}$ & $16.3-19.9$ & 19.0 & 14.9 \\
\hline $\mathrm{C}_{17: 0} 2-\mathrm{OH}$ & $\mathrm{ND}$ & $\operatorname{tr}$ & $\operatorname{tr}$ \\
\hline
\end{tabular}

*This fatty acid could not be identified with the MIDI system; its equivalent chain length is provided.

$\uparrow$ Summed features are groups of two or three fatty acids that cannot be separated by GLC with the MIDI system. Summed feature 3 contained $\mathrm{C}_{16: 1} \omega 7 c$ and/or iso- $\mathrm{C}_{15: 0} 2-\mathrm{OH}$; summed feature 4 contained anteiso- $\mathrm{C}_{17: 1} \mathrm{~B}$ and/or anteiso- $\mathrm{C}_{17: 1} \mathrm{I}$.

Table 2. Physiological and biochemical properties of strains of C. hominis and C. arothri

Data were obtained in this study. +, Positive; $(+)$, delayed positive; - , negative; v, variable, strain-dependent.

\begin{tabular}{|c|c|c|}
\hline Characteristic & C. hominis $(n=11)$ & C. arothri DSM $19326^{\mathrm{T}}$ \\
\hline \multicolumn{3}{|l|}{ Acid production from: } \\
\hline Glucose & + & + \\
\hline Sucrose & $\mathrm{V}$ & + \\
\hline Mannitol & - & - \\
\hline Arabinose & - & - \\
\hline Cellobiose & $\mathrm{V}$ & $(+)$ \\
\hline Lactose & - & - \\
\hline Maltose & + & + \\
\hline Trehalose & - & - \\
\hline Xylose & - & - \\
\hline Ethylene glycol & + & + \\
\hline \multicolumn{3}{|l|}{ Hydrolysis of: } \\
\hline Aesculin & + & + \\
\hline Tween 80 (7 days) & - & - \\
\hline Starch & + & + \\
\hline Tyrosine & $\mathrm{V}$ & - \\
\hline Gelatin & + & + \\
\hline Growth at $36-37{ }^{\circ} \mathrm{C}$ & + & + \\
\hline Growth on MacConkey agar & - & - \\
\hline Nitrate reduction & $\mathrm{V}$ & - \\
\hline Urease activity & - & - \\
\hline Indole production & + & + \\
\hline Acetate alkalinization & + & + \\
\hline Flexirubin pigments & - & - \\
\hline$\beta$-Galactosidase activity (ONPG) & - & - \\
\hline
\end{tabular}


of the DNA-DNA cross-hybridization yielded a relatedness of $100 \%$, whereas in reciprocal hybridization a lower value of $76 \%$ was obtained.

Based on the presented results, it is proposed to unite the species Chryseobacterium arothri Campbell et al. 2008 and Chryseobacterium hominis Vaneechoutte et al. 2007. According to Rules 38, 42 and $24 \mathrm{~b}(2)$ of the Bacteriological Code (Lapage et al., 1992), the name Chryseobacterium hominis has priority and hence should be used for the unified taxon, with Chryseobacterium arothri as a later heterotypic synonym.

\section{References}

Bernardet, J.-F., Nakagawa, Y. \& Holmes, B. (2002). Proposed minimal standards for describing new taxa of the family Flavobacteriaceae and emended description of the family. Int J Syst Evol Microbiol 52, 1049-1070.

Campbell, S., Harada, R. M. \& Li, Q.-X. (2008). Chryseobacterium arothri sp. nov. isolated from the kidneys of a pufferfish. Int J Syst Evol Microbiol 58, 290-293.

Kämpfer, P. \& Kroppenstedt, R. M. (1996). Numerical analysis of fatty acid patterns of coryneform bacteria and related taxa. Can J Microbiol 42, 989-1005.
Kämpfer, P., Dreyer, U., Neef, A., Dott, W. \& Busse, H.-J. (2003). Chryseobacterium defluvii sp. nov., isolated from wastewater. Int J Syst Evol Microbiol 53, 93-97.

Laffineur, K., Janssens, M., Charlier, J., Avesani, V., Wauters, G. \& Delmée, M. (2002). Biochemical and susceptibility tests useful for identification of nonfermenting gram-negative rods. J Clin Microbiol 40, 1085-1087.

Lapage, S. P., Sneath, P. H. A., Lessel, E. F., Skerman, V. B. D., Seeliger, H. P. R. \& Clark, W. A. (editors) (1992). International Code of Nomenclature of Bacteria. Bacteriological Code (1990 Revision). Washington, DC: American Society for Microbiology.

Martin, R., Riley, P. S., Hollis, D. G., Weaver, R. E. \& Krichevsky, M. I. (1981). Characterization of some groups of gram-negative nonfermentative bacteria by the carbon source alkalinization technique. J Clin Microbiol 14, 39-47.

Schreckenberger, P. C., Daneshvar, M. I., Weyant, S. R. \& Hollis, D. G. (2003). Acinetobacter, Achromobacter, Chryseobacterium, Moraxella and other nonfermentative gram-negative rods. In Manual of Clinical Microbiology, 8th edn, pp.749-779. Edited by P. R. Murray, E. J. Baron, J. H. Jorgensen, M. A. Pfaller \& R. H. Yolken. Washington, DC: American Society for Microbiology.

Vaneechoutte, M., Kämpfer, P., De Baere, T., Avesani, V., Janssens, M. \& Wauters, G. (2007). Description of Chryseobacterium hominis sp. nov. to accommodate clinical isolates biochemically similar to CDC groups II-h and II-c. Int J Syst Evol Microbiol 57, 2623-2628. 